\title{
Strategi Pengembangan Program Sekolah Adiwiyata Nasional di Tingkat SMA Kota Pekanbaru
}

\author{
Nurhafni $^{1}$, Almasdi Syahza ${ }^{2}$, Auzar $^{2}$, Nofrizal $^{3}$ \\ ${ }^{1}$ Kepala Sekolah SMAN 7 Pekanbaru \\ ${ }^{2}$ Fakultas Keguruan dan Ilmu Kependidikan, Jalan Binawidya KM 12,5 Simpang Panam Universitas Riau \\ ${ }^{3}$ Program Studi Magister Ilmu Lingkungan Program Pascasarjana Universitas Riau \\ Jalan Pattimura No.09 Gedung I Gobah Pekanbaru, Telp. 0761-23742
}

\begin{abstract}
School is an important vehicle for educating and fostering people to understand and understand a science. In realizing a caring and cultured school, the school community needs to be involved in various environmental learning activities. In addition, schools are also expected to involve the surrounding community in conducting various activities that benefit both the school community, the community and the environment. These activities include creating extracurricular / curricular activities in the field of participatory-based environment in schools, participating in environmental action activities carried out by outsiders, building partnership activities or initiating the development of environmental education in schools, management and development of school supporting facilities. . School is a community that consists of students, teachers, principals, and administration and employees which is one of the effective mediums for learning and awareness of school residents. So that individuals, ranging from teachers, students and workers are involved in efforts to stop the rate of environmental damage caused by human hands. Creating a caring and cultured school requires a school management strategy that supports the implementation of environmental education by all school members in accordance with the basic principles of the Adiwiyata Program which is participatory and sustainable .
\end{abstract}

Key Words: Strategy, National Adiwiyata

Lajunya pertambahan penduduk dan meningkatnya kebutuhan manusia akan kebutuhan pangan dan papan menyebabkan lingkungan ikut dikorbankan untuk memenuhi kebutuhan hidup manusia karena antara manusia dan lingkungan terdapat hubungan timbal balik yang penting untuk saling memenuhi kebutuhannya. Menurut Sastrawijaya (2009), antara manusia dan lingkungan hidupnya terdapat hubungan timbal balik. Lingkungan mempengaruhi hidup manusia dan sebaliknya manusia dipengaruhi oleh lingkungan hidupnya. Lingkungan yang rusak adalah lingkungan yang tidak dapat lagi menjalankan fungsinya untuk mendukung kehidupan manusia.

Upaya meningkatkan kualitas hidup adalah sesuatu yang tidak dapat dihentikan karena setiap manusia selalu berusaha meningkatkan kualitas hidupnya. Dengan demikian, lingkungan merupakan bagian dari faktor pendukung dalam kualitas kehidupan manusia yang juga merupakan objek untuk memenuhi kebutuhan manusia. Bukan hanya karena peningkatan pertumbuhan penduduk, perubahan yang cepat dalam peradaban dan keragaman meningkatnya kebutuhan manusia juga membuat sumber daya alam berkurang karena upaya untuk memenuhi kebutuhan manusia.

Lingkungan secara luas digunakan di mana akan mengurangi daya dukungnya. Manusia akan mengeksploitasi sumber daya alam dalam skala besar untuk memenuhi kebutuhan mereka dan jika eksploitasi ini tidak dilakukan dengan bijaksana, akan ada kesenjangan lingkungan yang berdampak pada kerusakan lingkungan .

Masalah lingkungan yang semakin meningkat dalam bentuk pencemaran lingkungan dan berkurangnya sumber daya alam membutuhkan pemahaman tentang upaya pelestarian lingkungan. Undang-Undang Nomor 32 Tahun 2009 tentang Perlindungan dan Pengelolaan Lingkungan Hidup pada poin keempat pasal 65 menyatakan bahwa setiap orang berhak dan berperan dalam pengelolaan lingkungan.Ini berarti bahwa baik Pemerintah dan masyarakat memiliki kewajiban untuk berpartisipasi dalam upaya perlindungan dan pengelolaan lingkungan 
Sekolah sebagai lembaga pendidikan dan tempat pendidikan adalah target utama untuk terlibat dalam pengelolaan lingkungan melalui implementasi setiap mata pelajaran di dunia pendidikan.Pendidikan sekolah adalah salah satu bagian dari kegiatan untuk mendidik penerus bangsa dalam mempromosikan kecerdasan intelektual serta mendidik moralitas dan karakter. Tujuan pendidikan karakter adalah membangun karakter setiap siswa untuk membangun kepribadian dan perilaku positif melalui lingkungan yang dapat mempengaruhi pengetahuan manusia, keterampilan, dan kesejahteraan untuk kegiatan sosial .

Undang-undang nomor 20 Tahun 2003 yang berkaitan dengan Sistem Pendidikan Nasional mengatakan bahwa pendidikan adalah upaya sadar dan terencana untuk menciptakan suasana belajar dan proses sehingga siswa akan secara aktif mengembangkan potensi untuk memiliki kekuatan spiritual, pengendalian diri, kepribadian, kecerdasan, akhlak mulia, dan keterampilan yang dibutuhkan untuk kemakmuran masyarakat, bangsa, dan negara. Ada alternatif rasional untuk masalah ini yaitu memasukkan pendidikan lingkungan dalam kurikulum .

Pendidikan lingkungan merupakan salah satu faktor penting dalam keberhasilan pengelolaan lingkungan dan juga merupakan alat yang sangat penting untuk menghasilkan sumber daya manusia yang dapat menerapkan prinsip pembangunan berkelanjutan. Nurjhani dan Widodo (2009) percaya bahwa pendidikan lingkungan diperlukan dan harus diberikan kepada anak-anak sejak usia dini sehingga mereka akan mengerti dan tidak akan merusak lingkungan. Hal ini dipengaruhi oleh beberapa aspek termasuk (1) aspek kognitif: pendidikan lingkungan memiliki fungsi untuk meningkatkan pemahaman masalah lingkungan serta meningkatkan memori, aplikasi, analisis, dan evaluasi, (2) aspek afektif : pendidikan lingkungan adalah berfungsi untuk meningkatkan penerimaan, penilaian, organisasi, kepribadian, dan karakteristik dalam mengelola kehidupan agar selaras dengan alam, (3) aspek psikomotor: pendidikan lingkungan berperan untuk meniru dan memanipulasi interaksi dengan lingkungan sekitarnya dalam upaya untuk meningkatkan budaya mencintai lingkungan, dan (4) aspek minat: pendidikan lingkungan digunakan untuk meningkatkan minat pada anak-anak .

Pendidikan Lingkungan di Indonesia telah ditempuh oleh berbagai pihak sejak awal tahun 1970-an. Sejak itu, pelaksanaan Pendidikan Lingkungan dilakukan secara terpisah oleh masing-masing agen pendidikan lingkungan. Saat ini, disadari bahwa berbagai upaya yang telah, sedang, dan akan dilakukan dalam pendidikan lingkungan perlu diperhatikan oleh semua pemangku kepentingan sehingga efektivitas pembangunan pendidikan lingkungan menjadi lebih terencana, konsisten, dan terstruktur .

Pentingnya melestarikan lingkungan harus dipahami oleh semua orang sehingga kontinuitas dan keseimbangan hidup dapat dipertahankan. Pemahaman ini harus diajarkan dari generasi ke generasi.Dasar untuk memahami pentingnya lingkungan harus dipahami oleh orang-orang dalam sistem ini di mana mereka akan memiliki kemampuan untuk berpikir dan memiliki hati nurani untuk menangkap informasi, budaya, dan teknologi (Soerjani, 2007).

Kesadaran akan pentingnya lingkungan perlu diajarkan dan perlu dilakukan sejak dini agar nilai-nilai mencintai lingkungan akan tertanam. Diharapkan bahwa nilai-nilai yang tertanam cinta untuk lingkungan akan terus meningkat pengetahuan dan pemahaman tentang pentingnya lingkungan sehingga dapat meningkatkan kesadaran melestarikan lingkungan .

Pengetahuan dan pemahaman tentang pentingnya lingkungan dapat diperoleh melalui pendidikan formal dan pendidikan non-formal. Pendidikan formal terstruktur yang terdiri dari pendidikan dasar, pendidikan menengah, dan pendidikan tinggi. Sementara itu, pendidikan nonformal adalah sistem pendidikan yang tidak mirip dengan pendidikan formal. Jika pendidikan formal dilaksanakan dalam struktur, pendidikan non-formal adalah dalam bentuk pendidikan yang diperoleh melalui keluarga dan lingkungan (Mendiknas, 2003).

Pendidikan formal adalah dunia pendidikan dalam ruang atau lembaga formal untuk menyampaikan pemahaman dan pengetahuan tentang lingkungan. Ini berarti bahwa lembaga pendidikan atau sekolah adalah penting "kendaraan" untuk mendidik dan membina 
masyarakat untuk memahami ilmu. Pemahaman dan pemahaman lingkungan tidak cukup untuk disampaikan dalam bentuk pesan lingkungan tetapi perlu diimplementasikan lebih lanjut sebagai ilmu di kedua subjek monolitik dan terintegrasi. Ini dapat membuat siswa lebih dituntut untuk memahami pentingnya lingkungan.

Dengan keterlibatan sekolah dalam upaya ini, peran pemerintah sangat penting untuk mengontrol pelaksanaan sekolah pemahaman dan pengetahuan lingkungan. Pemahaman tentang lingkungan telah dimasukkan dalam salah satu subyek berdasarkan kesepakatan antara Menteri Lingkungan Hidup dan Menteri Pendidikan Nasional dengan nomor Keputusan:Kep no 7 / MENLH / 06/2005 Nomor: 05 / VI / KB / 2005 tentang Pengembangan dan Pengawasan Pendidikan Lingkungan pada tanggal 5 Juni 2005. Keputusan ini menjadi surat resmi dan dasar untuk mendorong dan mengembangkan pendidikan lingkungan dengan penekanan bahwa pendidikan lingkungan dilakukan secara terpadu dengan mata pelajaran yang ada .

Pemerintah yang, dalam hal ini, adalah Kementerian Lingkungan Hidup, terus memainkan perannya dalam mempromosikan pendidikan lingkungan untuk dimasukkan dalam kurikulum sekolah.Secara formal, pendidikan lingkungan adalah salah satu alternatif rasional untuk memasukkan pendidikan lingkungan ke dalam kurikulum monolitik. Pendidikan Lingkungan Hidup (lingkungan pendidikan atau PLH) adalah mata pelajaran yang terintegrasi dengan mata pelajaran lain di sekolah .

Kementerian Lingkungan Hidup bekerja sama dengan Kementerian Pendidikan dan Kebudayaan mendorong sekolah untuk menciptakan lingkungan budaya sekolah yang ramah lingkungan dengan mengadakan kompetisi Sekolah Budaya Lingkungan (Sekolah Berbudaya Lingkungan) atau dikenal sebagai Program Adiwiyata . Program ini diluncurkan pada Tahun 2006 sebagai tindak lanjut MoU tertanggal 3 Juni 2003 , antara Menteri Lingkungan Hidup dan Menteri Pendidikan Nasional.

Program Adiwiyata dimulai pada Tahun 2006 dan hanya terfokus di Pulau Jawa karena masih dalam tahap mencari model untuk kriteria. Namun, sejak Tahun 2007, program ini telah dilakukan secara menyeluruh $(\mathrm{KLH}$, 2010).

Ternyata manajemen sekolah dalam kondisi dan situasi tertentu ditangani oleh guru dan siswa dengan budaya "kurang sadar lingkungan" karena pengecualian mereka dari partisipasi aktif serta kecenderungan apatis dan nondukungan terhadap sekolah-sekolah di lingkungan sekitarnya. Secara psikologis, itu menciptakan perasaan tidak nyaman ketika siswa melakukan kegiatan belajar mengajar. Di sisi lain, Pemerintah melalui program Sekolah Adiwiyata yang berorientasi lingkungan bergantung pada peran siswa dan semua aktor dalam kegiatan belajar mengajar sebagai aktor utama dalam mencapai Kualitas Sekolah Adiwiyata .

Dalam mewujudkan budaya dan kesadaran lingkungan, warga sekolah perlu dilibatkan dalam berbagai kegiatan pembelajaran lingkungan. Sekolah juga diharapkan melibatkan masyarakat sekitar dalam pelaksanaan berbagai kegiatan yang bermanfaat bagi warga sekolah, masyarakat, dan lingkungan. Ini termasuk menciptakan kegiatan ekstrakurikuler dan kurikuler yang didasarkan pada sekolah-sekolah di daerah sekitarnya, berikut kegiatan lingkungan yang dilakukan oleh orang lain, membangun kegiatan kemitraan, memulai pengembangan pendidikan lingkungan di sekolah-sekolah, serta mengelola dan mengembangkan fasilitas sekolah.

Berkaitan dengan masalah lingkungan yang semakin berkembang dan beraneka ragam, perlu memiliki pengelolaan sehingga lingkungan yang ada yang mengalami penurunan kualitas tidak menjadi lebih buruk dan bisa menjadi lebih baik. Untuk mengantisipasi upaya ini, pembangunan nasional diarahkan untuk menerapkan konsep pembangunan ramah lingkungan atau juga dikenal sebagai pembangunan berkelanjutan. Salah satu elemen dalam konsep pembangunan berkelanjutan adalah pendidikan lingkungan .

Secara formal, pendidikan lingkungan adalah alternatif yang rasional untuk memasukkan mata pelajaran ini ke dalam kurikulum. Pendidikan lingkungan merupakan salah satu faktor penting dalam keberhasilan pengelolaan lingkungan dan juga merupakan alat yang sangat penting untuk menghasilkan 
sumber daya manusia yang dapat menerapkan prinsip pembangunan berkelanjutan (Yustina, 2006).

Sekolah adalah sebuah komunitas yang terdiri dari siswa, guru, kepala sekolah, dan karyawan. Ini adalah salah satu medium efektif yang akan diterapkan untuk kegiatan belajar para warga sekolah. Oleh karena itu, individu mulai dari guru, siswa, dan karyawan terlibat untuk menghentikan laju kerusakan lingkungan yang disebabkan oleh manusia (KLH, 2005). Dalam pelaksanaan Pendidikan Lingkungan (PLH) di Sekolah Adiwiyata, ada beberapa hal yang belum dilaksanakan seperti tidak adanya guru atau buku pegangan siswa, silabus, struktur penilaian, kebijakan yang ketat dari kepala sekolah, dan dukungan dari pihak eksternal.

Sejalan dengan latar belakang di atas yang didasarkan pada masalah sistem manajemen sekolah yang harus ramah lingkungan dengan cara melestarikan sumber pencemaran lingkungan yang disebabkan oleh perilaku proses belajar mengajar, desain fasilitas pendukung yang tidak ramah lingkunganramah, serta kemungkinan membentuk nilainilai ramah lingkungan untuk masyarakat yang dapat dimulai sejak usia dini.

\section{BAHAN DAN METODE}

Jenis penelitian ini adalah penelitian eksploratif (studi kasus). Pada tahap awal, ada pengelompokan variabel analisis di lokasi penelitian yang ada di beberapa Sekolah Menengah Atas Pekanbaru. Penelitian ini juga dilakukan pada aktor kegiatan belajar mengajar serta manajer sekolah yang memiliki kegiatan dengan set sampel berdasarkan pendekatan metode orang kunci. Sejumlah data yang diperoleh melalui wawancara denganresponden terpilih juga akan dilakukan dengan metode wawancara mendalam (Bungin, 2008). Sebagai sampel penelitian, informan kunci adalah manajer sekolah dan pembuat kebijakan yang dianggap mewakili untuk mendapatkan data yang diperlukan. Data awal ini akan menjadi dasar untuk penyusunan kuesioner penelitian. Sebagai responden, informan kunci adalah siswa, guru, kepala sekolah, dan staf administrasi. Penelitian ini dilakukan dari bulan September hingga November 2017 di beberapa SMU Pekanbaru seperti SMAN 2, SMAN 4,
SMAN 5, SMAN 6, dan SMAN 9 yang telah memenangkan penghargaan sekolah nasional Adiwiyata serta SMAN 7, SMAN 10, dan SMAN 14 yang belum memenangkan penghargaan sekolah nasional Adiwiyata .

Penentuan sampel dalam penelitian ini tidak mirip dengan proses sampling seperti dalam penelitian kuantitatif. Sampling dalam penelitian ini disebut subjek penelitian. Subjek penelitian adalah orang / narasumber / informan yang dapat memberikan data / informasi kepada peneliti di lokasi penelitian. Penentuan subjek penelitian dalam penelitian kualitatif dilakukan secara purposif dan berkesinambungan. Penting juga untuk dicatat bahwa sifatnya tergantung pada tujuan penelitian kapan saja. Lebih lanjut, Nasution (1988) menambahkan bahwa "sampling dalam penelitian kualitatif-kualitatif adalah keputusan untuk membuat pilihan dari populasi manusia dan non-manusia."

Penelitian ini juga menggunakan data primer dan data sekunder. Data primer diperoleh langsung dari sumber data utama untuk melengkapi informasi yang diinginkan di lokasi / objek penelitian.Sedangkan data sekunder adalah data dan informasi yang diperoleh dari sumber tidak langsung yang biasanya berupa dokumen data. Selain itu, data sekunder adalah data pendukung atau pelengkap pada data primer .

Dalam penelitian ini, analisis data dilakukan melalui analisis data kualitatif. Data yang telah dikumpulkan diolah dan dianalisis untuk menjawab masalah penelitian dan hipotesis. Data yang diperoleh diatur sesuai dengan tuntutan penyajian / pengolahan statistik yang akan digunakan dalam bentuk tabel frekuensi atau persentase .

Pada tahap pengolahan data, pengeditan data dilakukan untuk memastikan bahwa pengisian masing-masing instrumen pengumpulan data dilakukan dengan sempurna. Setelah itu, pengkodean dilakukan dalam lembar matriks untuk digunakan dalam tabulasi data baik melalui lintas atau prosedur tunggal. Adapun tabulasi data, interpretasi atau kesimpulan diwujudkan dengan melakukan uji korelasi product moment correlation (Pearson) untuk mencari faktor-faktor yang mempengaruhi pencapaian Sekolah Nasional Adiwiyata di SMA Pekanbaru . 


\section{HASIL}

\section{Pengembangan Kegiatan Lingkungan Berbasis Partisipatif}

Komponen Pengembangan Kegiatan Lingkungan Berbasis Partisipatif dalam penelitian ini melibatkan beberapa indikator yang digunakan sebagai alat ukur. Keberadaan indikator pada komponen / variabel ini pada dasarnya diharapkan dapat membantu mengilustrasikan berbagai hal terkait dengan rumusan masalah yang akan dibahas .

Pada awalnya, indikator dalam variabel komponen ini terkait dengan kegiatan ekstrakurikuler atau kurikuler yang mendukung habituasi lingkungan siswa. tingkah laku. Pada dasarnya, ada banyak indikasi yang terkait dengan indikator ini. Namun, indikator ini mencoba untuk melihat apakah seluruh rentang kegiatan ekstrakurikuler dan kurikuler di lokasi penelitian adalah tempat yang membantu untuk membiasakan atau mengakomodasikan perilaku yang peka terhadap lingkungan secara umum. Berdasarkan data yang dikumpulkan dan dianalisis, diketahui bahwa status indikator ini relatif moderat. Hal ini dapat dilihat dari Tabel 1 di bawah ini.

Tabel 1. Kegiatan dalam ekstrakulikuler atau kulikuler yang mendukung pembiasaan perilaku berbudaya LH peserta didik

\begin{tabular}{clcc}
\hline No & Kondisi & Frekuensi & $\begin{array}{c}\text { Persentase } \\
(\%)\end{array}$ \\
\hline 1 & Sangat & 1 & 12,5 \\
& bagus & & \\
2 & Baik & 2 & 25,5 \\
3 & Sedang & 1 & 12,5 \\
4 & Kurang & 4 & 50 \\
5 & Sangat & - & - \\
& kurang & & 100 \\
\hline \multicolumn{2}{r}{ Total } & 8 & \\
\hline
\end{tabular}

Tabel 1 menjelaskan bahwa dari delapan sekolah yang diteliti, hanya ada satu sekolah Sangat Baik, satu sekolah Sedang, dan dua sekolah Baik yang terkait dengan indikator ini. Sementara itu, empat sekolah lainnya berada dalam status Kurang. Fakta ini jelas menunjukkan bahwa keberadaan indikator ini, sebagai bagian dari konsep Adiwiyata, masih belum diperhitungkan oleh masing-masing sekolah yang bersangkutan pada umumnya. Indikator berikutnya yang merupakan bagian dari komponen / variabel Pengembangan
Kegiatan Lingkungan Berbasis Partisipatif adalah adanya kegiatan lingkungan yang dilakukan oleh sekolah-sekolah yang melibatkan masyarakat di sekitar lingkungan sekolah. Keberadaan indikator ini umumnya mencakup berbagai kegiatan yang berkaitan dengan lingkungan baik dalam skala besar maupun kecil yang pelaksanaannya melibatkan unsur-unsur masyarakat di sekitar sekolah. Dari data yang didapat, diketahui bahwa keberadaan indikator ini bisa dikatakan rendah. Kondisi detail yang terkait dengan indikator ini dapat dilihat pada Tabel 2 di bawah ini :

Tabel 2. Kegiatan lingkungan yang diprakarsai oleh sekolah -sekolah yang melibatkan masyarakat di sekitar lingkungan sekolah

\begin{tabular}{clcc}
\hline No & Kondisi & Frekuensi & $\begin{array}{c}\text { Persentase } \\
(\mathbf{\%})\end{array}$ \\
\hline $\mathbf{1}$ & Sangat bagus & - & - \\
$\mathbf{2}$ & Baik & 2 & 25 \\
$\mathbf{3}$ & Sedang & 2 & 25 \\
$\mathbf{4}$ & Kurang & 4 & 50 \\
$\mathbf{5}$ & Sangat & - & - \\
& kurang & & $\mathbf{1 0 0}$ \\
\hline & Total & $\mathbf{8}$ &
\end{tabular}

Secara umum, uraian dari Tabel 2 jelas menunjukkan bahwa sekolah-sekolah masih melakukan kegiatan yang berkaitan dengan lingkungan secara individual dengan tingkat keterlibatan yang rendah dari masyarakat. Keberadaan jarak sosial antara sekolah dan masyarakat yang diilustrasikan oleh data yang ada sebenarnya menunjukkan bahwa integrasi dalam melihat isu lingkungan sebagai masalah bersama belum terealisasi. indikator di atas menunjukkan hasil yang buruk, indikator lain dalam komponen / variabel kegiatan lingkungan yang diprakarsai oleh sekolah yang melibatkan masyarakat di sekitar lingkungan sekolah akan menunjukkan hasil yang berbeda. Seperti yang diilustrasikan pada Tabel 3 di bawah ini, indikator yang terkait dengan kegiatan lingkungan yang diprakarsai oleh pihak eksternal yang diikuti oleh sekolah menunjukkan bahwa sekolah-sekolah dalam penelitian ini cenderung memiliki keterlibatan yang relatif baik : 
Tabel 3 . Kegiatan lingkungan yang diprakarsai oleh pihak eksternal diikuti oleh sekolah

\begin{tabular}{clcc}
\hline No & Kondisi & Frekuensi & $\begin{array}{c}\text { Persentase } \\
(\boldsymbol{\%})\end{array}$ \\
\hline 1 & Sangat bagus & 1 & 12,5 \\
2 & Baik & 3 & 37,5 \\
3 & Sedang & 1 & 12,5 \\
4 & Kurang & 3 & 37,5 \\
5 & Sangat kurang & - & - \\
\hline & Total & $\mathbf{8}$ & $\mathbf{1 0 0}$ \\
\hline
\end{tabular}

Ada tiga sekolah yang memiliki status yang (Kurang) indikator yang buruk sementara tiga s sekolah lainnya memiliki status indikator yang baik. Ada juga satu sekolah yang menunjukkan indikator Sangat Baik. Hal ini menunjukkan bahwa sekolah masih terlibat dalam kegiatan lingkungan yang diprakarsai oleh pihak eksternal meskipun memiliki kualitas dan kuantitas yang rendah.

Sesuai dengan indikator sebelumnya, indikator lain dalam komponen / variabel Pengembangan Kegiatan Lingkungan Berbasis Partisipatif dalam bentuk kegiatan kemitraan yang dilakukan oleh sekolah dengan pihak eksternal (lembaga terkait, pihak swasta, LSM) dalam pengembangan pendidikan lingkungan menunjukkan keadaan baik. Tabel berikut dapat membantu memahami keberadaan indikator ini di lokasi penelitian .

Tabel 4. Kegiatan kemitraan yang dilakukan oleh sekolah dengan pihak eksternal (lembaga terkait, pihak swasta, LSM) dalam pengembangan pendidikan lingkungan

\begin{tabular}{clcc}
\hline No & Kondisi & Frekuensi & $\begin{array}{c}\text { Persentase } \\
(\boldsymbol{\%})\end{array}$ \\
\hline 1 & Sangat bagus & 2 & 25 \\
2 & Baik & 3 & 37,5 \\
3 & Sedang & 2 & 25 \\
4 & Kurang & 1 & 12,5 \\
5 & Sangat & - & - \\
& kurang & & 100 \\
\hline & Total & 8 &
\end{tabular}

Tabel 4 menunjukkan bahwa keterlibatan sekolah dengan pihak lain untuk mengembangkan pendidikan lingkungan telah ditetapkan meskipun kualitas di setiap sekolah berbeda. Dari hasil wawancara, terungkap bahwa bentuk kolaborasi yang paling umum dilakukan oleh sekolah dengan pihak eksternal adalah kegiatan pengembangan kapasitas dan pengetahuan warga sekolah tentang lingkungan. Jenis kegiatan ini bisa dalam bentuk seminar, kamp pramuka, dan sebagainya.

Sesuai dengan tabel di atas, dapat dilihat bahwa SMAN 6 Pekanbaru, SMAN 7 Pekanbaru, dan SMAN 10 Pekanbaru termasuk dalam kategori kurang dalam hal Kegiatan Ekstrakurikuler yang mendukung perilaku lingkungan. Meskipun demikian, SMAN 6 Pekanbaru, SMAN 9 Pekanbaru, SMAN 10 Pekanbaru, dan SMAN 14 Pekanbaru memiliki kondisi pelaksanaan yang buruk. Juga diketahui bahwa partisipasi sekolah di lingkungan yang diprakarsai oleh pihak eksternal dari SMAN 7 Pekanbaru, SMAN 10 Pekanbaru, dan SMAN 14 Pekanbaru memiliki status kurang kategori. Last but not least, kegiatan kemitraan sekolah dengan pihak eksternal dari SMAN 7 Pekanbaru juga dalam kategori kurang.

\section{Pengembangan dan Pengelolaan Ramah Lingkungan Fasilitas Pendukung Sekolah}

Telah disebutkan bahwa ruang lingkup penelitian ini mencakup empat komponen / variabel utama, salah satunya adalah Pengembangan dan Pengelolaan Fasilitas Pendukung Sekolah Ramah Lingkungan. Keberadaan komponen / variabel ini memiliki arti yang sama dengan komponen / variabel lainnya. Untuk mengetahui kondisi variabel / komponen ini di lokasi penelitian, beberapa indikator akan diformulasikan untuk digunakan sebagai alat ukur yang akan dievaluasi dan dianalisis nanti sehingga referensi atau strategi untuk mewujudkan sekolah Adiwiyata dapat diperoleh. Salah satu indikator yang termasuk dalam variabel Pengembangan dan Pengelolaan ramah lingkungan Sekolah Fasilitas Penunjang adalah penggunaan fasilitas pendukung untuk sekolah sebagai media untuk belajar tentang lingkungan. Dari data yang tersedia, diketahui bahwa keberadaan indikator ini seimbang antara kondisi baik dan buruk. Hal ini terjadi karena fakta bahwa tiga dari delapan sekolah memiliki status yang Baik sementara dua lainnya memiliki status Kurang. Oleh karena itu, kondisi ini digambarkan sebagai berikut : 
Tabel 5. Penggunaan sekolah fasilitas pendukung

\begin{tabular}{clcc}
\multicolumn{4}{c}{ sebagai media lingkungan belajar } \\
\hline No & kondisi & Frekuensi & $\begin{array}{c}\text { Persentase } \\
(\%)\end{array}$ \\
\hline 1 & Sangat Baik & - & - \\
2 & Baik & 3 & 37,5 \\
3 & Sedang & 3 & 37,5 \\
4 & Kurang & 2 & 25 \\
5 & Sangat kurang & - & - \\
\hline & Total & 8 & 100 \\
\hline
\end{tabular}

SMAN 7 Pekanbaru dan SMAN 14 Pekanbaru memiliki status Kurang dalam pemanfaatan fasilitas pendukung sekolah sebagai media untuk belajar tentang lingkungan. Ini terjadi karena terbatasnya sumber daya pengajaran dalam optimalisasi fasilitas yang ada. Dengan kata lain, ini terjadi karena rendahnya kualitas guru dalam mensinergikan materi yang ada dengan isu lingkungan yang menjadi perhatian banyak orang .

Selain itu, indikator berikutnya yang perlu dibahas adalah sarana dan prasarana sekolah yang ramah lingkungan. Kondisi indikator ini di lokasi penelitian juga tidak bisa dikatakan bagus tetapi juga tidak bisa dikatakan buruk. Jadi, untuk membuatnya mudah, kondisi ini diilustrasikan sebagai berikut :

Tabel 6. Pengelolaan sarana dan prasarana sekolah yang ramah lingkungan

\begin{tabular}{clcc}
\hline No . & Kondisi & Frekuensi & $\begin{array}{c}\text { Persentase } \\
(\%)\end{array}$ \\
\hline 1 & Sangat Baik & - & - \\
2 & Baik & 2 & 25 \\
3 & Sedang & 5 & 62,5 \\
4 & Kurang & 1 & 12,5 \\
5 & Sangat kurang & - & - \\
\hline & Total & 8 & 100 \\
\hline
\end{tabular}

Upaya untuk mengelola fasilitas sanitasi untuk mendukung para kebersihan dan kesehatan sekolah. Sejauh pengamatan dilakukan, sanitasi sekolah sudah tersedia tetapi ada beberapa unit yang tidak berfungsi dengan baik. Faktor pemeliharaan dikenal sebagai faktor utama yang sering menyebabkan tidak berfungsinya fasilitas sanitasi yang ada. Secara umum, kondisi indikator ini dapat dilihat pada Tabel 7 :
Tabel 7. Upaya untuk mengelola fasilitas sanitasi

\begin{tabular}{|c|c|c|c|}
\hline No. & Kondisi & Frekuensi & $\begin{array}{c}\text { Persentase } \\
(\%)\end{array}$ \\
\hline 1 & Sangat Baik & - & - \\
\hline 2 & Baik & 2 & 25 \\
\hline 3 & Sedang & 4 & 50 \\
\hline 4 & Kurang & 2 & 25 \\
\hline 5 & Sangat kurang & - & - \\
\hline & Total & 8 & 100 \\
\hline
\end{tabular}

Tabel di atas jelas menunjukkan bahwa hanya ada dua sekolah yang memiliki status Kurang seperti SMAN 6 Pekanbaru dan SMAN 10 Pekanbaru. Sementara itu, SMAN 4 Pekanbaru, SMAN 5 Pekanbaru, SMAN 7 Pekanba ru, dan SMAN 14 Pekanbaru memiliki fasilitas sanitasi moderat. Selain itu, SMAN 2 Pekanb aru dan SMAN 9 Pekanbaru memiliki fasilitas sanitasi yang lebih baik .

Indikator berikutnya yang keberadaannya juga perlu dijelaskan adalah indikator yang terkait dengan efisiensi penggunaan air, listrik, alat tulis, plastik, dan bahan lainnya. Kondisi keseluruhan indikator ini di lokasi penelitian adalah sebagai berikut :

Tabel 8. Upaya untuk menggunakan secara efisien dengan air, listrik, alat tulis , plastik, dan bahan lainnya

\begin{tabular}{clcc}
\hline No. & Kondisi & Frekuensi & $\begin{array}{c}\text { Persentase } \\
(\%)\end{array}$ \\
\hline 1 & Sangat Baik & 1 & 12,5 \\
2 & Baik & 3 & 37,5 \\
3 & Sedang & 3 & 37,5 \\
4 & Kurang & 1 & 12,5 \\
5 & Sangat & - & - \\
& kurang & & 100 \\
\hline
\end{tabular}

Berdasarkan hasil wawancara dan observasi, diketahui bahwa pola efisiensi yang dilakukan di setiap sekolah untuk setiap jenis hal cenderung memiliki kesamaan. Namun, pengawasan dan kesinambungan pola belum dilakukan dengan benar di masing-masing sekolah. Untuk menghemat air, hal yang umum dilakukan oleh pengelola sekolah adalah menyosialisasikan penghematan air dengan berkampanye untuk menutup keran jika sudah digunakan atau jika bak penuh. Namun, perlu juga dipahami bahwa ketersediaan air bersih dalam kualitas dan kuantitas tidak sama di setiap sekolah. Ini mirip dengan pola 
untuk menghemat listrik, alat tulis, plastik, dan bahan lainnya, terutama benda-benda yang bisa dibuang.

Dari data yang dikumpulkan melalui kuesioner dan wawancara, kita dapat melihat bahwa upaya mengelola kantin sehat atau makanan di sekolah telah dilakukan dengan kualitas moderat. Namun, kantin sekolah yang dianggap dikelola dengan cara yang bersih dan sehat sangat terbatas. Oleh karena itu, representasi dari indikator ini dapat dilihat pada Tabel 9.

Tabel 9. Upaya untuk mengelola kantin atau makanan sehat di sekolah

\begin{tabular}{clcc}
\hline No & Kondisi & Frekuensi & $\begin{array}{c}\text { Persentase } \\
(\%)\end{array}$ \\
\hline 1 & Sangat Baik & 1 & 12,5 \\
2 & Baik & 2 & 25 \\
3 & Sedang & 4 & 50 \\
4 & Kurang & 1 & 12,5 \\
5 & Sangat kurang & - & - \\
\hline & Total & 8 & 100 \\
\hline
\end{tabular}

Kondisi kantin dan distribusi makanan sehat di sekolah tidak sepenuhnya menjadi tanggung jawab sekolah tetapi juga para siswa dan manajer kantin atau penjual makanan. Pola manajemen kantin yang didasarkan pada kontrak, kontrol kualitas, dan kondisi makanan dapat dilakukan dengan cara yang lebih teratur. Padahal, lebih sulit mengendalikan makanan yang dijual oleh penjual lain yang berada di luar area sekolah.

Indikator berikutnya yang juga perlu diperhatikan adalah upaya pengelolaan sampah untuk menciptakan lingkungan yang bersih dan sehat di sekolah. Hasil pengamatan dan wawancara yang didukung oleh tabulasi kuesioner menunjukkan bahwa, di sekolahsekolah, indikator ini telah mendapat perhatian. Perhatian terhadap indikator ini menunjukkan bahwa ini memang dianggap penting tetapi, pada tingkat praktik, ini menerima perhatian yang tampaknya sedikit tidak tepat. Penilaian yang diperoleh dari para pemimpin sekolah menunjukkan bahwa hanya ada satu sekolah dengan status Sangat Baik dan dua sekolah dengan status Baik. Empat sekolah lainnya memiliki status Sedang sementara satu sekolah menerima status Kurang. Ilustrasi yang jelas tentang indikator ini dapat dilihat pada tabel berikut .

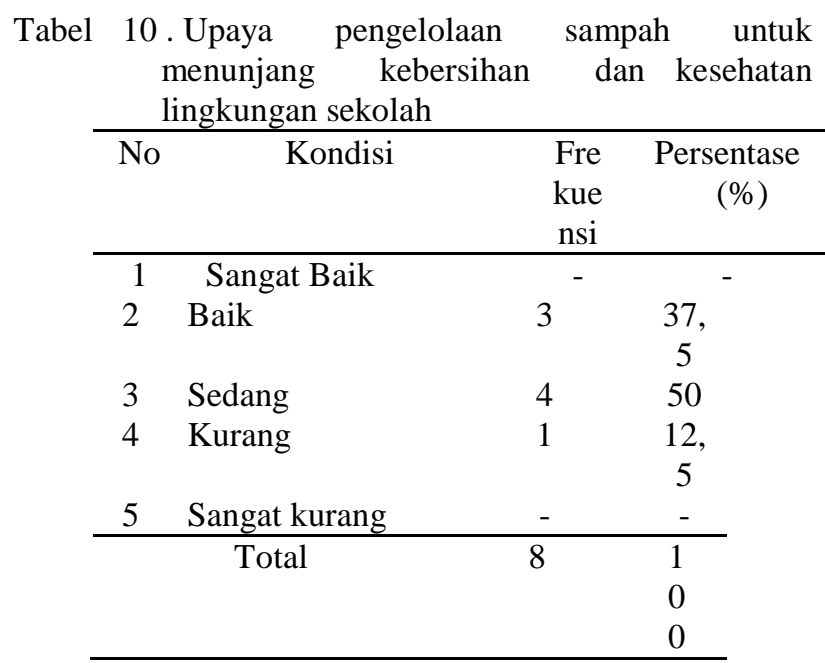

\section{PEMBAHASAN}

Inventarisasi faktor internal dan eksternal di Sekolah Tinggi Pekanbaru adalah :

\section{Sekolah lingkungan .}

Kebijakan sekolah terkait dengan keprihatinan sekolah terhadap budaya lingkungan. Sekolah yang telah membuat kebijakan terkait dengan kesadaran dan budaya lingkungan harus ditingkatkan. Ini berarti bahwa sebagian komponen sekolah Adiwiyata telah dilaksanakan di beberapa sekolah menengah atas di Pekanbaru .

\section{Pengembangan kurikulum lingkungan}

Terkait dengan pengembangan kurikulum pendidikan lingkungan, sekolah-sekolah mengacu pada kebutuhan siswa. Oleh karena itu, evaluasi periodik pengembangan kurikulum pendidikan lingkungan yang ada sangat diperlukan. Tidak hanya mengevaluasi konten tetapi juga mengevaluasi proses dan metode. Pengaruh kurikulum dan strategi pembelajaran kebijakan dalam mendukung pencapaian kualitas sekolah seperti sebuah lingkungan untuk mengevaluasi afektif program pembelajaran .

Kegiatan rutin tahunan dilaksanakan dengan tema lingkungan. Sesuai kebijakan sekolah, penyelenggaraan kegiatan atau acara lingkungan dapat berupa perayaan hari lingkungan, penanaman sejuta pohon (satu orang satu pohon), serta penerapan kesadaran higienis dengan operasi semut dan lain-lain. Pelaksanaan kegiatan ini jelas sesuatu yang dapat dilihat dalam tampilan biasa 


\section{Pengembangan sumber daya manusia}

Meningkatkan tingkat sumber daya manusia tentu akan meningkatkan pengetahuan dan wawasan lingkungan dari komunitas sekolah. Dengan meningkatnya pengetahuan dan wawasan ini, tentu akan mempengaruhi pengelolaan lingkungan .

\section{Sosialisasi Aplikasi Lingkungan}

Bisa dalam bentuk sosialisasi rutin melalui peraturan sekolah tetapi juga sosialisasi sementara melalui forum diskusi, seminar, dan sebagainya. Sosialisasi rutin melalui pendidikan sekolah merupakan upaya yang akan efektif untuk mengingatkan warga sekolah tentang pentingnya sekolah. Menerapkan peraturan sekolah yang pro-lingkungan seperti larangan membuang sampah secara acak (membuang sampah sembarangan), menghemat air dan kertas, dan yang lain akan secara langsung mengingatkan warga sekolah tentang pentingnya melindungi lingkungan

\section{Upaya untuk menggunakan fasilitas air dan sekolah secara efisien}

Secara umum, semua sekolah menunjukkan bahwa efisiensi penggunaan air, listrik, alat tulis, plastik, dan materi lainnya berjalan dengan baik sehingga dapat dipastikan bahwa setiap sekolah memiliki kondisi yang sama pada khususnya. Penerapan pendidikan lingkungan sejalan dengan kebijakan sekolah untuk membuat efisiensi pada hal-hal yang berkaitan langsung dengan kelestarian lingkungan .

\section{Sekolah yang bersih dan sehat}

Konsep bersih tentu tidak hanya terkait dengan dimensi kesehatan tetapi juga terkait dengan dimensi psikologis. Lingkungan sekolah yang bersih dan sehat menggambarkan kondisi di mana semua komponen lingkungan berada dalam kondisi seimbang. Keseimbangan dalam konteks ini tentu terkait dengan kesesuaian antara daya dukung fasilitas lingkungan yang tersedia dan kebutuhan komunitas sekolah .

\section{Manajemen anggaran}

Sekolah yang peduli dan berbudaya mengembangkan kebijakan sekolah untuk mengalokasikan dana untuk kegiatan lingkungan. Alokasi dana yang rendah dapat mengganggu pelaksanaan program atau kegiatan lingkungan .

\section{SIMPULAN}

Berdasarkan hasil penelitian di beberapa SMA di Pekanbaru tentang wawasan lingkungan sekolah melalui program nasional Adiwiyata, dapat disimpulkan bahwa (1) Strategi pengembangan untuk sekolah lingkungan di semua sekolah menengah Pekanbaru diwujudkan dengan meningkatkan kesadaran siswa melalui dukungan orang tua, meningkatkan kerjasama dengan sekolah lain, meningkatkan wawasan dan pengetahuan lingkungan siswa, meningkatkan wawasan siswa ke lingkungan, mengembangkan kegiatan lingkungan dengan masyarakat, dan meningkatkan kerja sama dengan pondasi lingkungan. (2) Pengelolaan dan pemanfaatan sarana dan prasarana semua sekolah menengah di Pekanbaru sudah berjalan dengan baik dilihat dari penyediaan beberapa fasilitas yang peduli terhadap lingkungan .

\section{UCAPAN TERIMA KASIH}

Penulis mengucapkan terimakasih kepada pihak-pihak yang telah membantu baik dalam bentuk materiil dan moril dalam penelitian ini, sehingga dapat terlaksana dengan baik penelitian ini.

\section{DAFTAR PUSTAKA}

Adam, A. 2014. Analisis Implementasi

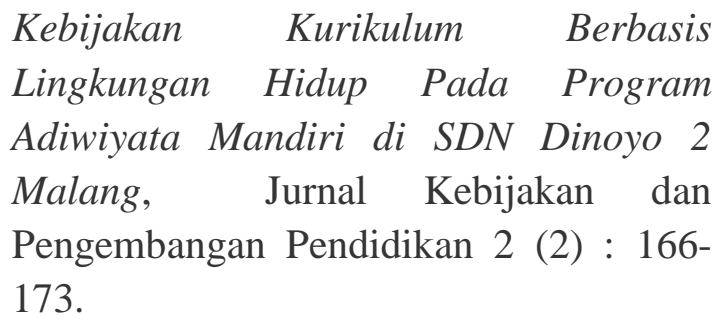

Afandi, R. 2013. Integrasi Pendidikan Lingkungan Hidup Melalui Pembelajaran IPS di Sekolah Dasar Sebagai Alternatif Menciptakan Sekolah Hijau, Pendagogia, 2 (1) : 98-108.

Bahrudin, M.D.F. 2017. Pelaksanaan Program Adiwiyata Dalam Mendukung Pembentukan Karakter Peduli Lingkungan di SMA Negeri 4 Pandeglang, Jurnal Pendidikan Geografi, 17 (1) .

Bungi, B. 2008. Analisis Data Penelitian Kualitati. Raja Grafindo Persada. Jakarta. Desfandi, M. 2015. Mewujudkan Masyarakat Berkarakter Peduli Lingkungan Melalui 
Program Adiwiyata. SOSIO DIDAKTIKA: Social Science Education Journal, 2(1) : 31-37.

Handayani, T., Wuryadi dan Zamroni. 2015. Pembudayaan Nilai Kebangsaan Siswa Pada Pendidikan Lingkungan Hidup Sekolah Dasar Adiwiyata Mandiri, Yogyakarta: Universitas Negeri Yogyakarta, Jurnal Pembangunan Pendidikan: Fondasi dan Aplikasi, 3 (1) : 95-105.

Hidayati, N., Taruna, T dan H. Purnaweni. 2014. Perilaku Warga Sekolah Dalam Implementasi Adiwiyata di SMK Negeri 2 Semarang, Jurnal Gea, 14 (1), UNDIP, Semarang.

Iswari, R.D, dan Utomo, S.W. 2017. Evaluasi Penerapan Program Adiwiyata Untuk Membentuk Perilaku Peduli Lingkungan di Kalangan Siswa (Kasus: SMA Negeri 9 Tangerang Selatan dan MA Negeri 1 Serpong). Jurnal Ilmu Lingkungan, 15(1),35-41.

Kadorodasih. 2017. Implementasi Pendidikan Lingkungan Hidup Melalui Program Adiwiyata di SD Negeri Giwangan Yogyakarta, Jurnal Hanata Widya, 6 (4).

Kementrian Lingkungan Hidup. 2010. Panduan Adiwiyata. Kementerian Lingkungan Hidup. Jakarta.

Kementrian Lingkungan Hidup. 2006. Garisgaris besar isi materi PLH. Jakarta.

Landriany, E. 2014. Implementasi Kebijakan Adiwiyata Dalam Upaya mewujudkan Pendidikan Lingkungan Hidup di SMA Kota Malang, Jurnal Kebijakan dan Pengembangan Pendidikan, 2 (1) : 82-88.

Maryani, I. 2014. Evaluasi Pelaksanaan Program Sekolah Adiwiyata ditinjau dari Aspek Kegiatan Partisipatif di SDN Ungaran I Yogyakarta, Jurnal Pemikiran dan Pengembangan SD, 1 (3) : 225-229.

Nasution, S. 1988. Metode Penelitian Naturalistik Kualitatif. Tarsito. Bandung.

Nurjhani, M dan widodo, A. 2009. Penggunaan Multimedia Untuk Meningkatkan Penguasaan Konsep Mahasiswa dalam Perkulihaan 'Konsep Dasar IPA', Prodi Pendidikan Guru Sekolah Dasar FIP: Tidak diterbitkan.frd
Paparang, O.E. 2017. Peran Serta Warga Sekolah Dalam Melaksanakan Program Adiwiyata di SMA Negeri 9 Lempake Samarinda, eJournal Administrasi Negara, 5 (2).

Rahmah, Y.D., S.S.Indradi dan Riyanto. 2017. Implementasi Program Sekolah Adiwiyata, Universitas Brawijaya. Jurnal Administrasi Publik, 2 (4) : 753-757.

Rozikin. 2016. Efektivitas Implementasi UKLUPL dalam mengurangi Kerusakan Lingkungan, Malang: Universitas Brawijaya, Jurnal Administrasi Publik, 2 (1) : 161-168.

Sastrawijaya. 2009. Pencemaran Lingkungan. Rineka Cipta Jakarta.

Soerjani. 2007. Lingkungan Hidup (The Living Environment) Pendidikan, Pengelolaan Lingkungan dan Kelangsungan Pembangunan (Education, Environmental Management and Sustainable Development). Institut Pendidikan dan Pengembangan Lingkungan. Jakarta.

Sunarti, L.S., Isjoni dan Zulkarnaini. 2017. Pengaruh Implementasi Program Adiwiyata Terhadap Perilaku Warga Sekolah Pada Sekolah Adiwiyata Mandiri Di Kota Pekanbaru, Dinamika Lingkungan Indonesia, Juli 2017, 139-147. Suko, P. 2009. Model pembelajaran tematik dalam PLH (PLH) di Sekolah Dasar. Jurnal Pendidikan Dasar, (11) : 1- 3.

Trikinasih, H., Wuryadi dan Zamroni. 2015. Pembudayaan Nilai Kebangsaan Siswa Pada Pendidikan Lingkungan Hidup Sekolah Dasar Adiwiyata Mandiri. Jurnal Pembangunan Pendidikan: Fondasi dan Aplikasi 3 (1).

Yustina. 2006. Hubungan Pengetahuan Lingkungan dengan Persepsi Sikap dan Minat dalam Pengelolaan Lingkungan Hidup pada Guru Sekolah Dasar di Kota Pekanbaru. Jurnal Biogenesis, 2 (67-71).

Wuryastuti, S dan I. Ni'mah. 2013. Model Pembelajaran Berbasis Lingkungan Untuk Meningkatkan Kecakapan Hidup Mahasiswa Melalui Pembuatan Kompor Biogas (Penelitian Pada Pembelajaran Mata Kuliah Konsep Dasar Biologi di UPI Kampus Serang). Jurnal EduHumaniora 5 (2):113-120. 